\title{
Examining the Key Success Factors for Startups in the Kingdom of Bahrain
}

\author{
Muneera Abdulla Al Sahaf* \\ MBA Directorat. \\ Ahlia University, Manama, Bahrain. \\ E-mail: muneeraalsahhaf@outlook.com
}

\author{
Lamea Al Tahoo \\ Assistant Professor, Department of Management, Marketing and MIS. \\ Ahlia University, Manama, Bahrain. \\ E-mail: 1altahoo@ahlia.edu.bh
}

Received January, 2021; Accepted March, 2021

\begin{abstract}
With Bahrain Economic Vision 2030, aspiring the shift from an economy that depends on oil wealth to a diversified economy, including startup businesses. A number of startups in Bahrain have been growing at a rapid pace in various industries. This is a result of the excellent ecosystem, and support provided to startups by the government in Bahrain. This study aims to examine the key success factors of startups in the Kingdom of Bahrain. The quantitative method was the adopted approach, whereby data was collected to examine the impact of four selected variables; fund-raising, experience, knowledge, and partnerships on the success of startups in Bahrain. The quantitative findings outlined the importance of several factors that were perceived to have a significant influence on the success of Bahraini Startups, where the majority of respondents agreed/strongly that two of the examined factors are considered critical to succeed in startups in the Kingdom of Bahrain. These factors are experience and knowledge, which proved to have an active role to maintain the success of startups. However, the startups' founders disagreed on the impact of fund-raising and partnerships which are considered to have no major effect on the success of startups. Recommendations of this research include two segments; for founders is to seek more opportunities to enhance their knowledge and capitalize on their experiences, and for government entities to provide and improve training offerings, and facilitate founders' communication and assist them in reaching out to the investors and the supporting entities, which will provide ease for new startup entry to the market, and establishment of a clear vision with framework prior to embarking the new venture.
\end{abstract}

Keywords: Start-ups; Innovation; Entrepreneurship; Bahrain.

Type: Research paper



This work is licensed under a Creative Commons Attribution 4.0 International License.

DOI: 10.51325/ijbeg.v4i2.65

\section{Introduction}

The kingdom of Bahrain's geographic location had great effect throughout the country commerce history as a trading center. Bahrain Proved itself as a trading home to merchants from the GCC and beyond starting mid-19th century up to date. In 1932, Bahrain was the first GCC country to discover oil, which led to remarkable transformation in its economy. Noticeably, the kingdom, was also the first GCC country that started diversifying its economy rather than depending solely on oil and became a leading financial center. In 2008, his Majesty King Hamad bin Isa Al Khalifa, launched Kingdom of Bahrain' 2030 economic vision, which is a comprehensive vision that provides a pathway for continuous developments in Bahrain's economy. 
Implementing his Majesty's vision, the Economic Development Board (EDB) was established in order to coordinate with government and non government parties to achieve 2030 economic vision. EDB has been encouraging investment in many sectors such as the financial services sector, manufacturing sector, and as well as focusing on startup businesses. Bahrain has a diversified economy that continue to grow. With the provided governmental support, Bahrain's startups are expanding at a rapid pace in various industries. The governmental support includes offering startup funding, management expertise, as well as an efficient regulatory environment leading to a supporting ecosystem including incubators and business accelerators, and work spaces. Whilst financial support is being provided by the governmental supporting entities such Bahrain Development Bank, Tamkeen, or private venture capital such as Tenmou. In addition to providing opportunities to acquire knowledge and education through Community, meetups, workshops, Tech startup events. Startups are described by Cockayne Startups, as small in terms of size and operation, are in the stage of creating client bases prior to growth (Cockayne, 2019). Skala (2019), defines startups as a firm that implement an innovative idea, however, an innovative product is not considered as an essential factor. The author also describes them as companies with little resources and expertise, who entered the market recently (Skala, 2019). While Marwick (2013), defines startups as a new, innovative type of work. Gill (2002), however, believes that startups are a combination of passion and work. More over, Cockayne (2016), states that startups are tasks being produced by founders themselves. While McRobbie (2002) thinks that startups are a developed way of living. Florida (2005) that supported that by indicating that entrepreneurs have interpersonal skills which enables them to promote their innovative ideas.

\section{The Research Problem}

This research has a significant importance as Bahrain is trying to generate young generation of startup's founders to enable them to lead, manage and be a productive member of society, contribute to delivering 2030 vision. This shed light as well as burden on startups to occupy a major segment of the economy and to contribute to preserve Bahrain's economy in the event of oil depletion, which makes success of startups a necessity. This study examines some of the success factors of startups in Bahrain. Four variables were selected including fundraising, experience, partnership, and knowledge, to assess their impact on the success of startups. Findings of this study is of value to founders who are in the planning stage of their innovative idea, it is also of value to government entities aiming at increasing the success rate of startups.

The study examined the effect of fund raising, role of experience, business knowledge, and partnership on the success of startups in the kingdom of Bahrain. Better understanding of the success factors of startups in the country, will drive business owners and investors to enhance and capitalize on their potential for growth and success as well as maintains of this success. 


\section{Literature Review}

The Middle East and North Africa (MENA) region is gifted with half of the reserve of oil and gas in the world. However, with the severe drop in oil reserve, MENA countries were reinforced to launch an ambitious economic vision aiming to increase the diversification of their economies revenue, specially by non-oil sectors. MENA oil producers' countries also witnessed a decline in labor productivity, due to the existence of a large gap in average wages, with public sector offering higher salaries and private wages with a difference of between $150 \%$ and $250 \%$ which is considered a major restriction for economic diversification in MENA hydrocarbon producers, as it prevents the development of an internationally-competitive private sector. (Tagliapietra, 2019). Meanwhile, with the drop in oil levels in MENA region and the limited job vacancies in workplaces related to the oil field, many countries including Bahrain have formulated new economic vision with focus to increase the private sector's role in the country's economy, assisting small and medium businesses to grow (SMEs), creating jobs and encouraging the non-oil sectors including startups businesses which is considered a major part of these sectors with a proven rapid growth in the Kingdom.

\section{Startups overview and perceptions}

An increasing growth toward startups is being recognised in the whole world, and in order to continue this growth, startups require maintaining and improving a continuous competitive-growth in order to succeed. (Robertson and Linus, 2017). Moreover, governments are encouraging startups to boost their growth and increase employments rates. On the other hand, Gill (2002), states that startup are a promising new and developed type of work, while others specifies the startups operations as schedules that founders create for themselves (Cockayne, 2016).

\section{General success factors of startups}

Startups success factors may vary among every stage, where some factors may have a greater impact in research and planning phase and less important in execution or fund raising. For instance, the psychology and personal traits of founders are recognized to have more impact in estimating the success probability of starting a new startup (Rauch, 2000).

The most important success factors of startups are outlined based on the startup's success factor framework. The success factors comprise of economic factors such as: financial resources, raising funds and continuous investments, another factor is innovation, which includes many variables such as: cumulative thinking, self-advancement and growth of entrepreneurial skills. Success factors may also consist of entrepreneurship and technology variables which consist of: entrepreneurship competitiveness, taking risk, driven by vision, creative utilization of technology, market-oriented technology and many other variables within each factor. These factors are utilized to facilitate the success of startups founders (Kim, 2018).

With many studies discussing the partnerships in startups and its impact on the success of startups, (Freytag, 2019) states that the main factors to success in convincing an 
established company to be a partner with a startup includes the strategic balance, owners sharing a similar vision and understanding the negotiation ceil.

(Schwarzkopf 2015) mentioned the startups success factors of the United States which was concluded through a literature search and through questionnaires, which helped in outlining the success factors of a startup. These factors include four general factors which can be examined in depth, which includes: the personal skills, the business qualities, the knowledge and education, pre-seeding and funding. Therefore, this research is studying the startups phenomena and their success factors, where the focus is on startups in the Kingdom of Bahrain. Meanwhile, startups' success factors vary in each country, business type, industry and startup stage. (Schwarzkopf 2015). The development of assessing success factors is prioritized by its importance and the extent of this factor continuity in all startup's stages. For these reasons and as the related research papers reviewed emphasizing on the importance of: Fund raising, Business Experience, Partnership and Business Knowledge as a key factors of startups success in all stages. Therefore, only these factors are selected to be examined in this research.

\section{Fund raising}

Startups are facing financing obstacles which is considered an essential issue to be addressed as it affects the economy of any country. The daily new businesses being established worldwide with an average of 137,000 per day (Mason, 2017), whilst the success of the startups mainly depends on the availability of funds (Stucki, 2013; Ghura et al., 2019; Hamdan et al., 2019; Harraf et al., 2020; Naqi and Hamdan, 2020; Reyad et al., 2020).

Some countries are using informal sources as a fund-raising source which comes with high financing rates due to the unavailability or the minor amount of established capital funding companies. Accompanied to the growth of startups, Rose, (2012) states that only $0.25-2 \%$ of the startups in the United States who lacks funds are actually receiving venture capital financing. Prohorovs (2019), refers to a similar emphasize on the importance of winning seed funding by startups founders. The researcher conducted a survey of 40 startups in which included the startups who was able to succeed and startups who failed in attracting funds and concluded that 15 was able to win funds, while 25 failed, taking into consideration the experience of the startups founders that has major effect on their ability to win seed funding.

On the other hand, (Tykvova et al., 2012) consider that funding is mostly needed by startups of high-tech industry startups in financing stage. While Prohorovs (2019), views fund raising as a critical factor in the success of startups during the initial launching stages and remains critical during the remaining stages of developing the business. Fund raising as a factor of success has been defined by many authors from different angles, according to (Freear, Sohl, and Wetzel 1995) who discussed the startup aspects showing that young investors tend to invest in seed funding 16 times mor than venture capital investors. 
However, as (Rose, 2012) states, only 1 company get the opportunity to raise funds out of 400 startups, others also confirms that an average of only $3 \%$ interaction among potential investor and startups founders ends with fund raising.

Nevertheless, (Mason 2006; Sudek 2007; Levesque 2014; Barinova 2015; Bernstein, et al,. 2017) confirms that the main factor affecting wining seed funds by a potential investor is through the founder's leadership skills which is classified as a key factor during the initial stage of a startup.

Taking into consideration that startups are part of the economic vision, participating in the country's economy and providing more job opportunities, therefore, solving the startups obstacles in lack of finance shall be considered as a key determinant of the success of the startups. (Tagliapietra, 2019) views that solving the finance problem for startups will create more than 15 million job vacancies within MENA region by 2025 which will assure the economic growth.

Many authors agree that the main factor to succeed in fund raising during any stage is the founders' experience and convincing skills which should be continuously enhanced during the startup stages. As determined by (Bachher and Guild 1996), the condition that affect an investor resolution to fund a startup includes five conditions: (1) Founders traits; (2) market research; (3) competitive outputs; (4) investor's conditions; (5) startup presentation. While (Freear et al., 1995, 2002) adds his vote to the founder's skills in convincing an investor as a key factor that impact wining a seed finance. The researcher also elaborated on the key characteristics of the founder's stating that reasons of failing to raise funds is the lack of knowledge and experience in executing the innovative ideas in addition to the unfeasible expectations which leads to adopting an over optimistic estimations leading to roads of failure.

Financing investors find the traits of reliability, truthfulness and enthusiasm of the founders of great effect on their decisions (Mason and Stark 2004). Likewise, (Sudek, 2007) made a quantitative and qualitative research of Californian financing angels and found that the main factor of winning a finance is the trustworthiness of startup founders. On the other hand, a different point of view upon studying the factors affecting closing a financing deal among a potential investor and a startup founder, revealed that it's the investor's intuition or empathy toward the founder.

Meanwhile, Accelerators are considered as a supportive entity providing many benefits to a startup with either low or free cost; if supported by the government, however, (Aldrich and Yang, 2012) refers to accelerators as an entity that provides a market entry assistance to startups founders. Accelerators main purpose is to improve startups and strengthen them during their initial stages, were many of the accelerators are provided by investors to assist startups' grow by providing access to many beneficial variables such as providing business mentors in addition to the assistance of creating their startup presentations. (Cohen, 2019). 
Governments are focusing on providing accelerators to startups considering it a positive involvement. Government-led accelerators goals are represented in getting new innovative founders to the field motivating the innovative founders, (Cohen, 2019). The same author states that Government-led accelerators have a high effect on the quality of startups growth, where it solves many setbacks that might face an entrepreneur, yet Government-led accelerators is undertaking a high risk by trying to keep the startups successful.

\section{Business Experience:}

Experience affects the startup in many different ways, it varies from a founder's experience derived from a work experienced in a similar industry or an experienced founder who comes from a family that owns a business, or an experience of a previously launched startup which succeeded or an experience of failure, along with the relatives and friends experience that affects the mindset of a founder toward businesses success or failure. (Ng and Saies, 2018; Jenkins, 2014; Ali and Hamdan, 2020; Al-Roubaie et al., 2020, Awwad and Zidan, 2021; Awwad, 2018) believed that founder's fear of failure impact startups greatly, where fear can be derived from a past experience or an adopted concept that failures carries social embarrassment.

(Ucbasaran et al., 2013) states that experience of failure and fear of social consequences can be an obstacle to a startup founder, and a barrier to his actions that might even prevent founders from launching their businesses. ( $\mathrm{Ng}$ and Saies, 2018).

Meanwhile, (Stephan \& Drencheva 2017) and (Lévesque and Stephan, 2019), find that experience have both influences; positive and negative, which can be a powerful tool that assist founders in their startups as they experienced how to raise funds or how to address any social issues. Whilst, negative past experiences can also be a strength factor that affects the learning and coping curve of a founder actions in a startup by amending strategies and overcoming the negative experience. While (Jenkins, et al,. 2014) research finds that re-entries by failed founders appears to be aligned with the same pattern stated by (Stephan \& Drencheva 2017) and (Lévesque and Stephan, 2019).

Inexperienced founders who have skills and a technical experience only brings a good product however a poor business model as well, (Prohorovs, et al,. 2019). Additionally, the authors states that the lack of business model and developments which requires the founder's experience, are the two main factors of a startup success during its initial stage, therefore experience influence startups greatly. (Cohen, 2019) confirms as well that the background of an entrepreneur can significantly affect the startup success through many aspects of business.

Whereas, experienced founders have a wider network and able to expand it further easily. Studies on New startup founders with prior experience are more likely to apply this experience and succeed (Wang and Gibb, 2020) Believes that experienced founders who 
develop a prototype have a richer content. Experienced founders are able to recall the knowledge and solve issues effectively comparing to inexperienced founders. And in contrast, (Diéguez et al,. 2020) finds that a founder with a family-owned startup have a negative effect on the probability of founders acquiring, partnering or creating a different startup. Further (Wang and Gibb, 2020), experienced founders are able to address problems and apply an adequate solution faster than an inexperienced founder which enables them to move forward with their startup faster as well.

With fund raising and financing being an essential part of the success of a startup, (Gompers et al., 2003) conclude that with the difficulties faced by most of the startups founders in financing and seed funding, despite that, many founders are receiving funds successfully as they manage to get the investors' trust through their experience and skills, hence seed funding are received.

(Prohorovs, 2018), investors consider an experienced founder as an added value to their evaluation of a startup investment. Government-led accelerators are most likely to get startups with inexperienced founder, while an investor-led accelerator are more likely to get an experienced entrepreneur, which suggest that investors are more likely to adopt and invest in an experienced founder's innovated idea who have a background and can execute a strategic plan, (Cohen, 2019).

\section{Partnership:}

An entrepreneurial team or co-founders of an innovative idea is described as a group of entrepreneurs with a similar vision and goals to reach with the required actions by both parties. Cantele (2020) consider the honesty and trust as a main factor for a partnership to succeed and (Morales 2019) stated that partnerships are comprised of a very attractive professional aspiration. (Cooney 2005) also defines the co-founders or partners as a 2 or more individuals who share a similar financial goal and participate in achieving this goal.

(Cantele, 2020) believes that partnerships is growing continuously where the knowledge and continuity is sustained within many different industries. While (Schjoedt and Kraus 2009) propose that the partnership composed of two or more individuals who share the same financial interest and commitment toward the partnership future and success. Partnerships exists in different shapes such as partnerships established among startups cofounders or between a founder and an established company. It is essential that each partner have a clear vision of the other partners' aims of this partnership (Freytag, 2019), also states in his research that the success of partnerships among a startup and an established company is possible in the terms of knowing each party's interest and taking it into consideration. (Hoegl and Gemuenden 2001) refer to the teamwork of startup co-founders or partnerships as an essential factor of startups.

Partnerships can have a promising advantage on a startup. (Freytag 2019), examined the partnership effect on startups and found that partnerships between a founder and an 
established company can give access to so many advantages such as: the acquisition of the client database, taking advantage of the available technology and operational capability which can reflect significantly on the startup development, were it can use the partners selling channels.

On the other hand, Freytag elaborate more in the potential advantages of a partnership among a founder and an established company geographical wise, were startups can expand through their partners' s geographical existence and utilizing it by creating a global reputation. (Freytag, 2019).

Moreover, having an established company as partner can give signals to other potential investors that the startup has a good anticipation of growth, in addition to the chance of having the startup fully acquired by its partner in case the founder needs to exit the business. On the other side, Startups can provide the established companies a look into the current trend of the market. (Freytag 2019).

The co-founders or partners of a startup is a key success factor at the early stages of a startup which creates a competitive advantage of the business and during the development of the products, and in attracting more investors to fund the business (Kaplan, Sensoy, Stromberg 2009).A setback of partnering with an established company is that companies might induce the start up to replace its initial strategy in order to further utilize from the outcomes of the partnership (Freytag 2019).

(Cantele, 2020) highlights that partners who are sharing a similar value, goals and parallel improvements in both parties increase the created value of the innovative output which guarantees the sustainability of a startup. On the other hand, the role of co-founders or startup partners is emphasized by (Mason, 2007; Sudek 2007), who states that they have a major role in affecting the decision of investing by a business angel. The two major factors affecting a successful startup is the co-founders team and the rate of growth in the market, whilst the products traits carry lesser effect. Bruno and Tyebjee (1985) who concluded that a weak management team of a startup is the main factor for startup failure. While others that partnerships create a competitive startup by adding a competitive skill to each task.

Using a sample of 4500 investors in early stage startups, shows that the team is a major factor with major influence to be considered for its success (Bernstein et al,.2017). The importance of partners goals alignments should be taken into consideration, where they are convinced of the value of the other partner or potential partner (Freytag 2019).

Partnership increase the startup capabilities to interact correctly toward different issues and helps overcoming setbacks due to the skills combination and flexibility (Cantamessa 2018), believes that lack of harmony among partners and co-founders and miscommunication, is an essential factor affecting the success of startups. 


\section{Knowledge}

Knowledge has always been an important of all times considering it an essential asset for individuals and therefore for businesses (Bender and Fish, 2000). Knowledge is a cognitive process of people. (Oliva and Kotabe, 2019). However, knowledge and education in specific product or industry is not presented as a major factor in decision making. (Prohorovs, 2018). In contradiction, startups with higher maturity stage are showing a higher degree of knowledge utilization. (Oliva and Kotabe, 2019).

(Mason and Stark 2004) addressed knowledge as vital when the potential investor have an experience in the same field of the startup, therefore, lack of knowledge in this case would affect the startup fund raising negatively. While (Toutain et al. 2017) thinks that early learning by students on the business planning process affects future founders positively.

Impact of founder's experience when they apply for related education perceiving an adequate knowledge, shows positive results in preparing the startup business plan and an overall positive effect on the founder's developments skills (Laine, et al., 2019).

Liñán (2007) indicates that prior knowledge of a founder increases self-efficacy. While (McCoshan et al., 2010) concluded that a founder knowledge has a positive effect on the competency of the business and on producing the desired outcome.

(Laine, K. et al. 2019) indicates that the effect of a founder's education and knowledge on a startup success may vary based on the business sector, as a result to the study, social and health care sector were affected significantly by the founder's knowledge. knowledge in startups is considered as a powerful administrative tool. (Oliva and Kotabe 2019). Due to knowledge effect in the startup growth and development, many accelerators provide educational programs to the founders. Accelerators provide education programs to fill the gap of understanding of a startup founder to guarantee the growth of the business. (Cohen, 2019).

(Cohen, 2019) finds a strong relation between the investor-led accelerators and startup founders' knowledge, where government-led accelerators founded by individuals with public knowledge may focus on economic growth, on the other hand, investor-led accelerators with investment background focus instead on profit maximization.

\section{Research Design and Methodology}

The research aimed to identify and analyze the relationship between a number of presumed influencing factors (independent variables) and success of startups (dependent variable) in the Kingdom of Bahrain. The approach was used to test the hypothesis raised to achieve the research objectives is a quantitative approach which is adopted to measure hypothesis in numerical terms; and to obtain in depth understanding about the effect of experience, partnership, fund raising and knowledge on the success of startups in Bahrain. 
Secondary data was from literature review (i.e. existing studies relevant to startups internationally). The data was mainly considered from several sources; including peer reviewed scholarly journal articles, books, official websites, regarding the success factors of startups. The primary data aimed to provide answers to research questions through quantitative approach; and a deeper analysis to the problem and assisted to reach to final conclusions and recommendations. The Quantitative approach includes designing online web-based questionnaire to explore the effect of the specific success factors on startups success in Bahrain. The approach followed in this research consists of four aspects. The first aspect is about the procedure and tools for collecting information. The second component is about the type of information collected. Numerical data extracted from webbased survey was used in quantitative research.

The conceptual framework was designed according to factors "independent variables" that influence the success of startups in Bahrain "dependent variable" which were identified in the literature review to examine the association relationship and the degree of influence through testing the following hypotheses:

\section{H1: The presumed success factors have significant positive impact on the success of startups in the Kingdom of Bahrain.}

H1-1: Raising funds from an investor or a financial supporting entity has significant positive impact on the success of startups in the Kingdom of Bahrain

H1-2: Having a business experience has significant positive impact on the success of startups in the Kingdom of Bahrain.

H1-3: Partnerships have a significant positive impact on the success of startups in the Kingdom of Bahrain.

H1-4: Having an industry and business knowledge have significant positive impact on the success of startups in the Kingdom of Bahrain.

\section{Population and Sample Size}

As mentioned earlier, the method used in this research 'quantitative' that led to targeting one population group. Which consist of founders of startups in the Kingdom of Bahrain; 535 was the number of active founders identified through Ministry of Industry Commerce $\&$ Tourism (MOICT) statistics. Two steps were followed to determine the number of founders to participate in the survey. Sample size formula was used as a first step, and then a finite population formula was used to reach to final sampling size needed. The sampling technique adopted in this research was non-probability sampling method, accidental and convenience sampling to target the population who represent the founders of startups in the Kingdom of Bahrain. This method was more suitable and attractive to use due to the quick and easy access to the necessary data, readiness of information and low cost. An electronic survey was designed through Monkey Survey, and the link was distributed among startup founders through e-mail, LinkedIn, and text to share the survey by other entrepreneurs who might know to reach the target sample. 


\section{Data Analysis and Testing}

\section{Descriptive Analysis}

This will be the first part to analyse data collected from survey in tables with demographic background; such as gender, age, nationality, education level, etc.

Table 1: Participants Responses to Demographic Questions

\begin{tabular}{|c|c|c|c|c|}
\hline No & Question & Answer Options & Frequency & Percent \\
\hline \multirow{3}{*}{1} & \multirow{3}{*}{ Gender } & Male & 86 & $37.07 \%$ \\
\hline & & Female & 146 & $62.93 \%$ \\
\hline & & Total & 232 & $100 \%$ \\
\hline \multirow{6}{*}{2} & \multirow{6}{*}{ Age } & Less than 25 years & 30 & $12.93 \%$ \\
\hline & & $26-35$ years & 106 & $45.69 \%$ \\
\hline & & $36-45$ years & 69 & $29.74 \%$ \\
\hline & & $46-55$ years & 14 & $6.03 \%$ \\
\hline & & Greater than 55 years & 13 & $5.60 \%$ \\
\hline & & Total & 232 & $100 \%$ \\
\hline \multirow{3}{*}{3} & \multirow{3}{*}{ Nationality } & Bahraini & 196 & $84.85 \%$ \\
\hline & & Non-Bahraini & 35 & $15.15 \%$ \\
\hline & & Total & 231 & $100 \%$ \\
\hline \multirow{5}{*}{4} & \multirow{5}{*}{$\begin{array}{l}\text { Educational } \\
\text { Background }\end{array}$} & Secondary School & 50 & $21.55 \%$ \\
\hline & & Bachelor Degree & 149 & $64.22 \%$ \\
\hline & & Master Degree & 29 & $12.50 \%$ \\
\hline & & Doctorate Degree & 4 & $1.72 \%$ \\
\hline & & Total & 232 & $100 \%$ \\
\hline \multirow{6}{*}{5} & \multirow{6}{*}{ startup stage } & Building Innovative idea & 57 & $24.57 \%$ \\
\hline & & Research and Planning & 29 & $12.50 \%$ \\
\hline & & Fund raising and execution & 49 & $21.12 \%$ \\
\hline & & Intermediate stage - brand built & 63 & $27.16 \%$ \\
\hline & & Expanding stage & 34 & $14.66 \%$ \\
\hline & & Total & 232 & $100 \%$ \\
\hline \multirow{5}{*}{6} & \multirow{5}{*}{ Work Experience } & Less than one year & 53 & $22.94 \%$ \\
\hline & & $1-2$ years & 27 & $11.69 \%$ \\
\hline & & $3-5$ years & 39 & $16.88 \%$ \\
\hline & & Greater than 5 years & 112 & $48.48 \%$ \\
\hline & & Total & 231 & $100 \%$ \\
\hline \multirow{4}{*}{7} & \multirow{4}{*}{ Type of Business } & Service & 86 & $37.23 \%$ \\
\hline & & Products & 122 & $52.81 \%$ \\
\hline & & Other & 23 & $9.96 \%$ \\
\hline & & Total & 231 & $100 \%$ \\
\hline
\end{tabular}

The result of the first question in the survey showed the majority of participants were females representing $62.93 \%$ of the sample size; while $37.07 \%$ were males. 


\section{Participants' Gender}

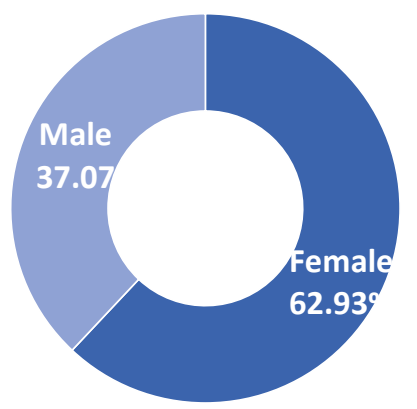

Figure 1: Diagram Showing the Participants' Gender

The majority of participants' age was between 26 - 35 years $(45.69 \%)$, between $36-45$ (29.74\%), less than 25 years $(12.93 \%)$, between $46-55$ years $(6.03 \%)$ and greater than 55 years $(5.60 \%)$.

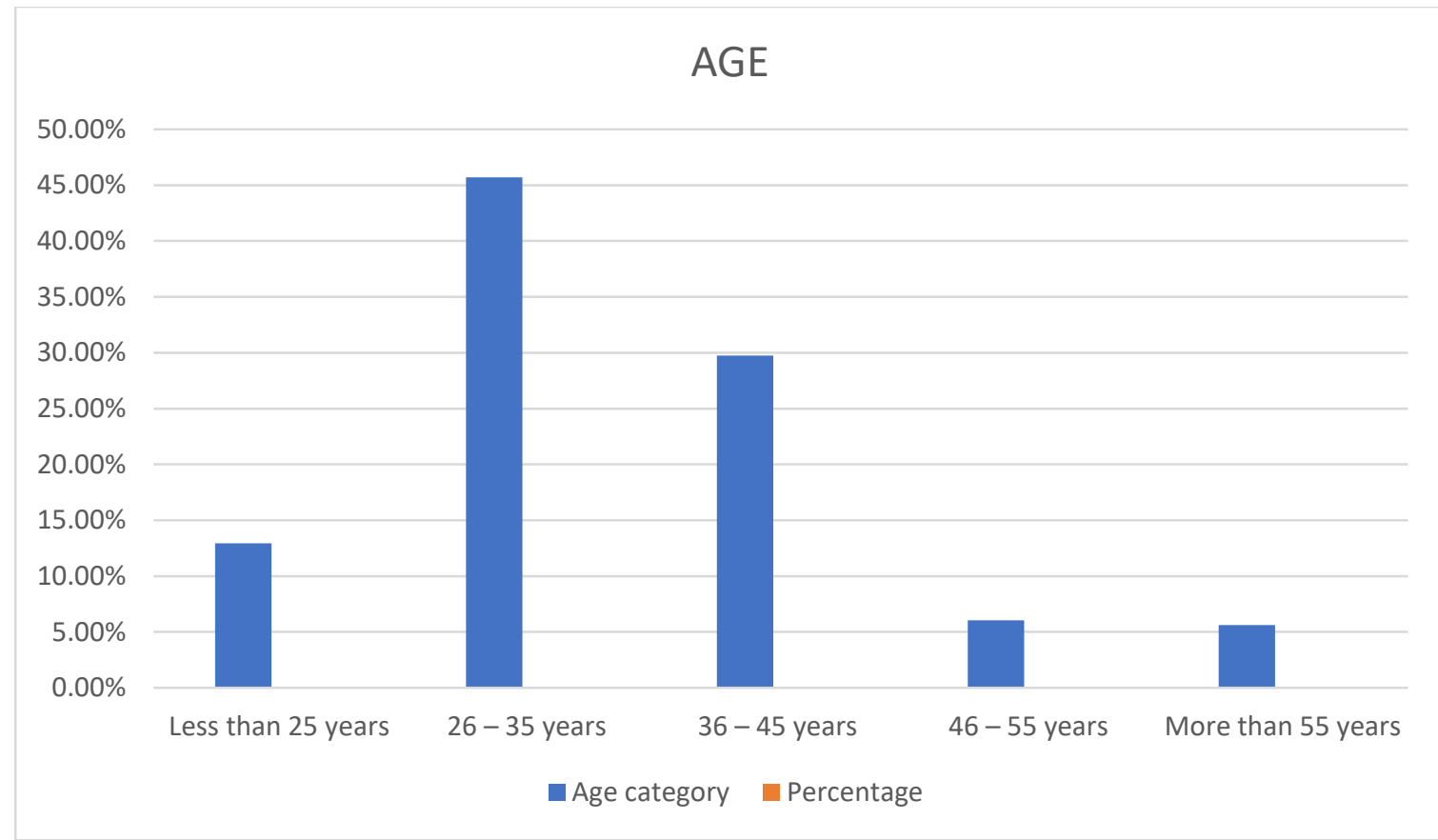

Figure 1: Diagram Showing the Participants' Age

Most participants' representing $84.85 \%$ were -Bahrainis; whereas, $15.15 \%$ were non Bahraini. In fact, Ministry of Industry, commerce \& Tourism (MOICT) results indicated that the number of Bahraini founders are marginally greater than the number of nonBahrainis. This is considered a positive finding which confirms the effect of the facilities provided to Bahraini founders specially by Tamkeen; financial supporting entity, in the Kingdom of Bahrain. Meanwhile, the percentage of non-Bahraini founders is growing on a slow pace. 


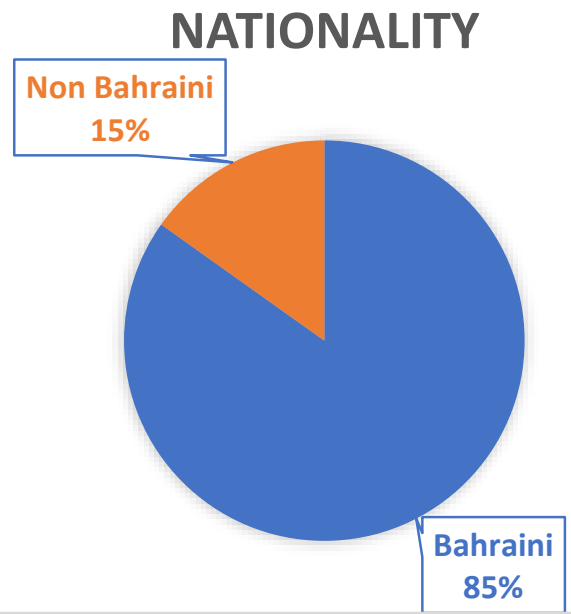

Figure 3: Diagram Showing the Participants' Nationality

Participants' educational level showed that the majority holding Bachelor degree with $64.22 \%$, then Secondary School with $21.55 \%$, Master degree with $12.50 \%$ and after that Doctorate degree with $1.72 \%$. The overwhelming majority holds Batchelor degree, indicating a moderate level of academic qualifications among respondents.

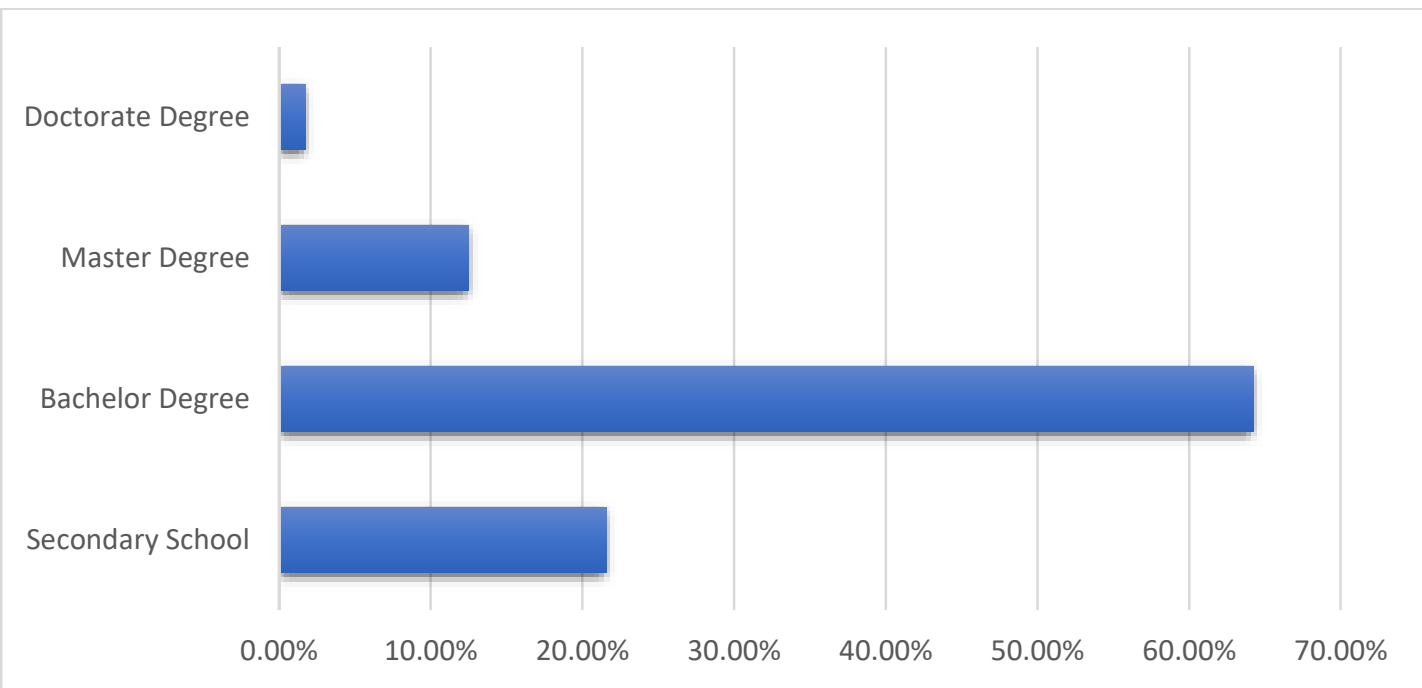

Figure 4: Diagram Showing the Participants' Educational Background

As for the startup stage ranking for the survey respondents; $27.16 \%$ have built their own brand and they are within their intermediate stage, $24.57 \%$ where building the innovative idea, $21.12 \%$ are raising funds and within the execution stage, $12.50 \%$ are within the research and planning stage, and $14.66 \%$ are expanding their businesses. 


\section{Startup Stage}

$30.00 \%$

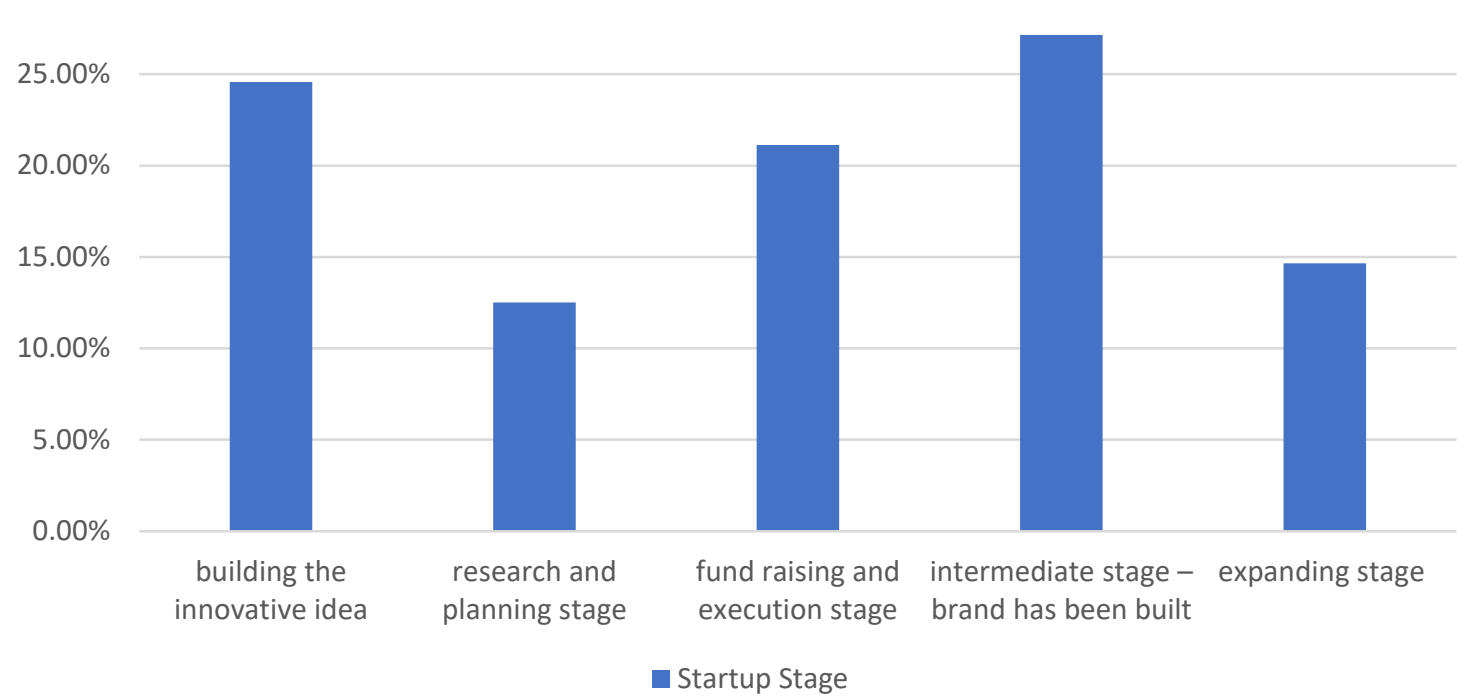

Figure 4: Diagram Showing the Participants' Startup Stage

The result showed that the majority of respondents who completed the survey, their years of work experience was greater than 5 years with $48.48 \%, 22.94 \%$ less than a year, $16.88 \%$ between 3 to 5 years, $11.69 \%$ between 1 to 2 years. This result is consistent with the preceding figures regarding respondents' age and academic qualifications.



Figure 5: Diagram Showing the Participants' Years of Work Experience

Type of the participants' type of business who responded to the survey was $52.81 \%$ producing products, $37.23 \%$ are providing services and $9.96 \%$ responded as others. It is worth noting that startup founders have a products innovative idea who represent approximately $53 \%$ of the overall population; while the remaining belong to services and other type of businesses. 


\section{TYPE OF BUSINESS}



Figure 6: Diagram Showing the Type of Participants' business

Participants responses have also revied some suggestions, these are summarized as follows:

1. Providing financial and emotional support in addition to preserve the founders' rights; financially and patent wise.

2. Promotional support by the governmental entities in the Kingdom of Bahrain.

3. Adopting an innovative, new ideas that does not exist in the Kingdom market as Bahrain is having a huge amount of red ocean businesses.

4. Conducting a and business plan before executing the business which affects the success of startup positively.

5. Providing the required support by the governmental entities using equalized opportunities and standard evaluation based on fixed standards and conditions.

6. Implement more regulating policies on startups and individual establishments to ensure quality of outputs.

7. Lowering the initial expenses by providing either financial support or by lowering the operational costs to support youth segment to pursue their innovative ideas.

8. Provide awareness to Bahraini community in order to create an investing mindset rather than saving mindset.

9. Apply exemption criteria on home businesses.

10. To implement Business coaching for all founders in all startup stages in addition to conducting trainings for founders on a regular basis.

11. Starting the research stage by exploring what problems' Bahraini market is facing and what does it lack as a product or service and follow it with a business plan.

12. Initiating a motive within Bahraini citizens to buy, invest, promote and support local businesses rather than international products or services.

13. Encouraging successful entrepreneurs offering mentorships to allow the younger generation's creativity to grow in the right path. 
14. Introduce startup business knowledge in school's syllabus in order to build the required knowledge and increase the success rate of startups in Bahrain.

15. Facilitate the entry of foreigner's individual establishments by providing virtual individual establishment Commercial Registration to expats in addition to allowing a fully owned expat Commercial registration.

16. Increase the international accelerators in Bahrain and coworking spaces for startups in addition to increasing the incubation period to 3 years.

17. Access of funding during all business stages would help upscale a startup within the region and assist in international expansion.

18. A reserve fund by the governmental supporting entities to have a continuous, nondisruptive support during crisis.

19. Setting up specific locations in the Kingdom for entrepreneurs to situate and promote their businesses with a minor fee.

20. Facilitate the import and export by startups in addition to hosting exhibitions for startup founder to introduce their businesses to clients, partners and investors.

\section{Descriptive of Variables \\ Frequency Testing:}

Four factors "variables" that influence startups success in the Kingdom of Bahrain was identified from literature review. The below table explores the founders' perspective about each factor effect on the success of startups in Bahrain. 
Table 1: Participants' Perspective about fund raising effect on the success of startup in the Kingdom of Bahrain.

\begin{tabular}{|c|c|c|c|c|c|c|c|c|}
\hline \multirow[b]{2}{*}{ Factors } & \multirow[b]{2}{*}{ Statements } & \multicolumn{5}{|c|}{ Frequency \% } & \multirow[b]{2}{*}{ Mean } & \multirow[b]{2}{*}{ Std. Deviation } \\
\hline & & $\begin{array}{c}\text { Strongly agree } \\
\text { (5) }\end{array}$ & $\begin{array}{l}\text { Agree } \\
\text { (4) }\end{array}$ & $\begin{array}{l}\text { Neutral } \\
\text { (3) }\end{array}$ & $\begin{array}{r}\text { Disagree } \\
\text { (2) }\end{array}$ & $\begin{array}{c}\text { Strongly disagree } \\
\text { (1) }\end{array}$ & & \\
\hline \multirow{5}{*}{ 1. Fund raising } & $\begin{array}{l}\text { 1.1. I started my } \\
\text { business using my } \\
\text { own Capital and I } \\
\text { didn't require any } \\
\text { fund raising }\end{array}$ & $\begin{array}{c}101 \\
43.7 \%\end{array}$ & $\begin{array}{c}48 \\
20.8 \%\end{array}$ & $\begin{array}{c}48 \\
20.8 \%\end{array}$ & $\begin{array}{c}22 \\
9.5 \%\end{array}$ & $\begin{array}{c}12 \\
5.2 \%\end{array}$ & 3.883 & 1.2191 \\
\hline & $\begin{array}{l}\text { 1.2. Fund raising is } \\
\text { only required in the } \\
\text { early stage of the } \\
\text { startup }\end{array}$ & $\begin{array}{c}25 \\
10.8 \%\end{array}$ & $\begin{array}{c}53 \\
22.9 \%\end{array}$ & $\begin{array}{c}80 \\
34.6 \%\end{array}$ & $\begin{array}{c}50 \\
21.6 \%\end{array}$ & $\begin{array}{c}22 \\
9.5 \%\end{array}$ & 3.039 & 1.1266 \\
\hline & $\begin{array}{l}\text { 1.3. I needed to raise } \\
\text { funds during all } \\
\text { stages and still } \\
\text { require it after the } \\
\text { launch of the } \\
\text { business even after } \\
\text { generating profit } \\
\text { and for expansion } \\
\text { reasons. }\end{array}$ & $\begin{array}{c}42 \\
18.2 \%\end{array}$ & $\begin{array}{c}73 \\
31.6 \%\end{array}$ & $\begin{array}{c}59 \\
25.5 \%\end{array}$ & $\begin{array}{c}40 \\
17.3 \%\end{array}$ & $\begin{array}{c}17 \\
7.4 \%\end{array}$ & 3.359 & 1.1780 \\
\hline & $\begin{array}{l}\text { 1.4. I was able to } \\
\text { convince an investor } \\
\text { to finance my } \\
\text { startup easily due to } \\
\text { my personal traits. }\end{array}$ & $\begin{array}{c}18 \\
7.8 \%\end{array}$ & $\begin{array}{c}48 \\
20.8 \%\end{array}$ & $\begin{array}{c}67 \\
29 \%\end{array}$ & $\begin{array}{c}44 \\
19 \%\end{array}$ & $\begin{array}{c}54 \\
23.4 \%\end{array}$ & 2.706 & 1.2511 \\
\hline & $\begin{array}{l}1.5 . \mathrm{I} \text { am/was } \\
\text { receiving financial } \\
\text { support from } \\
\text { Tamkeen for my } \\
\text { startup. }\end{array}$ & $\begin{array}{c}18 \\
7.8 \%\end{array}$ & $\begin{array}{c}32 \\
13.9 \%\end{array}$ & $\begin{array}{c}50 \\
21.6 \%\end{array}$ & $\begin{array}{c}46 \\
19.9 \%\end{array}$ & $\begin{array}{c}84 \\
36.4 \%\end{array}$ & 2.365 & 1.3106 \\
\hline
\end{tabular}




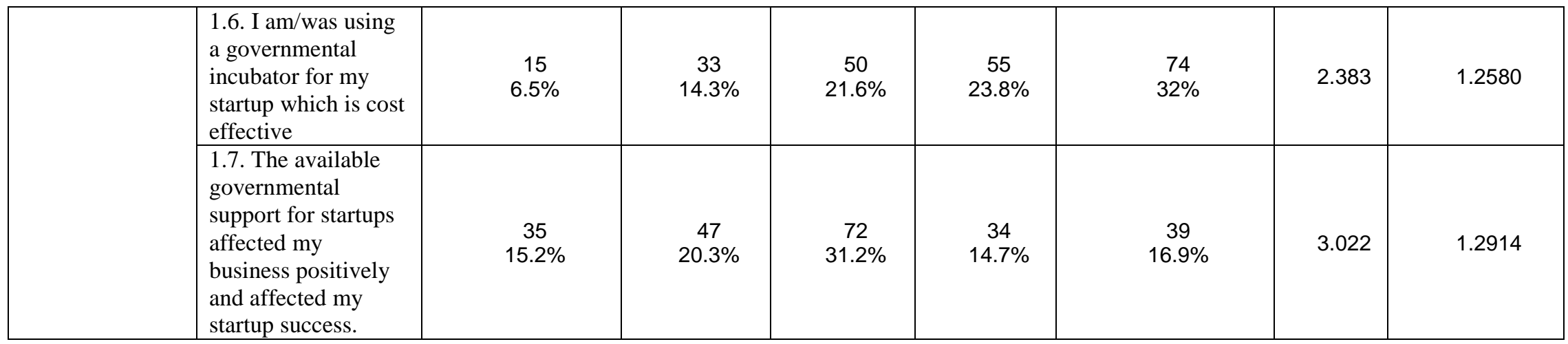

According to the findings for the first variable "Fund raising", the majority of respondents tend to agree with the significant impact of raising funds on the success of their startups, continuity and expanding (mean $\mu=3.5$ and Std. Deviation $=1.2$ ). In particular, respondents asserted that raising funds is needed during all startup stages, and also confirmed that most of the respondents started their startups using their own funds which shows the lack of funds provided by investors or supporting entities which is critical to assure the success of startups in Bahrain. Founders predominantly emphasized on inability to get a governmental financial support such as Tamkeen, nor their ability to convince an investor to fund their businesses and most of the respondents are not using incubators.

Table 2: Participants' Perspective about Experience effect on the success of startup in the Kingdom of Bahrain.

\begin{tabular}{|c|c|c|c|c|c|c|c|c|}
\hline \multirow[b]{2}{*}{ Factors } & \multirow[b]{2}{*}{ Statements } & \multicolumn{5}{|c|}{ Frequency $\%$} & \multirow[b]{2}{*}{ Mean } & \multirow[b]{2}{*}{$\begin{array}{r}\text { Std. } \\
\text { Deviation }\end{array}$} \\
\hline & & $\begin{array}{c}\text { Strongly agree } \\
(5)\end{array}$ & $\begin{array}{l}\text { Agree } \\
\text { (4) }\end{array}$ & $\begin{array}{c}\text { Neutral } \\
\text { (3) }\end{array}$ & $\begin{array}{l}\text { Disagree } \\
\text { (2) }\end{array}$ & $\begin{array}{c}\text { Strongly } \\
\text { disagree } \\
\text { (1) }\end{array}$ & & \\
\hline \multirow[t]{2}{*}{ 2. Experience } & $\begin{array}{l}\text { 2.1. I don't have } \\
\text { experience in } \\
\text { startups and this is } \\
\text { my first startup } \\
\text { business }\end{array}$ & $\begin{array}{c}78 \\
33.8 \%\end{array}$ & $\begin{array}{c}62 \\
26.8 \%\end{array}$ & $\begin{array}{c}38 \\
16.5 \%\end{array}$ & $\begin{array}{c}38 \\
16.5 \%\end{array}$ & $\begin{array}{c}13 \\
5.6 \%\end{array}$ & 3.672 & 1.2573 \\
\hline & $\begin{array}{l}\text { 2.2. I have } \\
\text { experience in } \\
\text { doing business as }\end{array}$ & $\begin{array}{c}31 \\
13.4 \%\end{array}$ & $\begin{array}{c}50 \\
21.6 \%\end{array}$ & $\begin{array}{c}44 \\
19 \%\end{array}$ & $\begin{array}{c}53 \\
22.9 \%\end{array}$ & $\begin{array}{c}48 \\
20.8 \%\end{array}$ & 2.836 & 1.3547 \\
\hline
\end{tabular}


The International Journal of Business Ethics and Governance (IJBEG), Vol.4, No. 2, 2021

\begin{tabular}{|c|c|c|c|c|c|c|c|}
\hline $\begin{array}{l}\text { my family owns } \\
\text { one }\end{array}$ & & & & & & & \\
\hline $\begin{array}{l}2.3 \text {. I started this } \\
\text { business because I } \\
\text { have experience in } \\
\text { the same field. }\end{array}$ & $\begin{array}{c}57 \\
24.7 \%\end{array}$ & $\begin{array}{c}78 \\
33.8 \%\end{array}$ & $\begin{array}{c}51 \\
22.1 \%\end{array}$ & $\begin{array}{c}25 \\
10.8 \%\end{array}$ & $\begin{array}{c}18 \\
7.8 \%\end{array}$ & 3.572 & 1.1995 \\
\hline $\begin{array}{l}\text { 2.4. I think failure } \\
\text { in a previous } \\
\text { startup will } \\
\text { support an } \\
\text { entrepreneur } \\
\text { positively in and } \\
\text { affect the success } \\
\text { of his current } \\
\text { startup. }\end{array}$ & $\begin{array}{c}67 \\
29 \%\end{array}$ & $\begin{array}{c}74 \\
32 \%\end{array}$ & $\begin{array}{c}73 \\
31.6 \%\end{array}$ & $\begin{array}{c}10 \\
4.3 \%\end{array}$ & $\begin{array}{l}2 \\
0.9 \%\end{array}$ & 3.858 & .9273 \\
\hline $\begin{array}{l}\text { 2.5. To experience } \\
\text { a failure will cause } \\
\text { me a social } \\
\text { embarrassment. }\end{array}$ & $\begin{array}{c}14 \\
6.1 \%\end{array}$ & $\begin{array}{c}30 \\
13 \%\end{array}$ & $\begin{array}{c}53 \\
22.9 \%\end{array}$ & $\begin{array}{c}73 \\
31.6 \%\end{array}$ & $\begin{array}{c}55 \\
23.8 \%\end{array}$ & 2.444 & 1.1756 \\
\hline
\end{tabular}

"Experience" was the second variable and the result showed that most of the startups founders is establishing their business for the first time, while many also confirmed having a previous experience in the same field of their startups, (mean $\mu=3.57$ and Std. Deviation $=1.19)$. Remarkably, most of respondents agreed that failure in a previous startup will support an entrepreneur positively and affect the success of his current startup. Nonetheless respondents did not agree that failure in a business can cause a social embarrassment, which will positively affect their experience in businesses, providing additional knowledge on how to succeed and avoid failure reasons (mean $\mu=2.44$ and Std. Deviation $=1.17>1$ ). 
Table 3: Participants' Perspective about Partnership effect on the success of startup in the Kingdom of Bahrain.

\begin{tabular}{|c|c|c|c|c|c|c|c|c|}
\hline \multirow[b]{2}{*}{ Factors } & \multirow[b]{2}{*}{ Statements } & \multicolumn{5}{|c|}{ Frequency \% } & \multirow[b]{2}{*}{ Mean } & \multirow[b]{2}{*}{$\begin{array}{c}\text { Std. } \\
\text { Deviation }\end{array}$} \\
\hline & & $\begin{array}{l}\text { Strongly } \\
\text { agree } \\
(5) \\
\end{array}$ & $\begin{array}{c}\text { Agree } \\
\text { (4) }\end{array}$ & $\begin{array}{c}\text { Neutral } \\
\text { (3) }\end{array}$ & $\begin{array}{c}\text { Disagree } \\
\text { (2) }\end{array}$ & $\begin{array}{c}\text { Strongly } \\
\text { disagree } \\
(1)\end{array}$ & & \\
\hline \multirow{5}{*}{ 3.Partnership } & $\begin{array}{l}\text { 3.1. I have a partner } \\
\text { in my startup. }\end{array}$ & $\begin{array}{c}34 \\
14.7 \% \\
\end{array}$ & $\begin{array}{c}55 \\
23.8 \% \\
\end{array}$ & $\begin{array}{c}26 \\
11.3 \% \\
\end{array}$ & $\begin{array}{c}54 \\
23.4 \% \\
\end{array}$ & $\begin{array}{c}62 \\
26.8 \% \\
\end{array}$ & 2.762 & 1.4445 \\
\hline & $\begin{array}{l}\text { 3.2. I prefer } \\
\text { partnerships with } \\
\text { individuals rather } \\
\text { than with } \\
\text { established } \\
\text { companies. }\end{array}$ & $\begin{array}{c}37 \\
16 \%\end{array}$ & $\begin{array}{c}53 \\
22.9 \%\end{array}$ & $\begin{array}{c}69 \\
29.9 \%\end{array}$ & $\begin{array}{c}39 \\
16.9 \%\end{array}$ & $\begin{array}{c}31 \\
13.4 \%\end{array}$ & 3.114 & 1.2584 \\
\hline & $\begin{array}{l}\text { 3.3. I believe that } \\
\text { partnership has a } \\
\text { positive effect on } \\
\text { the success of } \\
\text { startups }\end{array}$ & $\begin{array}{c}42 \\
18.2 \%\end{array}$ & $\begin{array}{c}74 \\
32 \%\end{array}$ & $\begin{array}{c}69 \\
29.9 \%\end{array}$ & $\begin{array}{c}26 \\
11.3 \%\end{array}$ & $\begin{array}{c}17 \\
7.4 \%\end{array}$ & 3.430 & 1.1378 \\
\hline & $\begin{array}{l}\text { 3.4. I choose to } \\
\text { have a partner with } \\
\text { capital rather than } \\
\text { having a partner } \\
\text { with experience } \\
\text { and knowledge. }\end{array}$ & $\begin{array}{c}18 \\
7.8 \%\end{array}$ & $\begin{array}{c}33 \\
14.3 \%\end{array}$ & $\begin{array}{c}79 \\
34.2 \%\end{array}$ & $\begin{array}{c}73 \\
31.6 \%\end{array}$ & $\begin{array}{c}24 \\
10.4 \%\end{array}$ & 2.771 & 1.0769 \\
\hline & $\begin{array}{l}\text { 3.5. Partnership } \\
\text { startups are more } \\
\text { successful than solo } \\
\text { startups. }\end{array}$ & $\begin{array}{c}23 \\
10 \%\end{array}$ & $\begin{array}{c}54 \\
23.4 \%\end{array}$ & $\begin{array}{c}86 \\
37.2 \%\end{array}$ & $\begin{array}{c}41 \\
17.7 \%\end{array}$ & $\begin{array}{c}22 \\
9.5 \%\end{array}$ & 3.066 & 1.1035 \\
\hline
\end{tabular}

The findings for the third factor "Partnership" where most respondents do not have partners in their startups (mean $\mu=2.76$ and Std. Deviation $=2.44$ ), however, they commonly agreed that having a partner would have a positive effect on the success of their businesses. This founder's view suggests that having is a key element, however, there participants were neutral concerning partnerships with established companies, or choosing a partner with capital rather than having a partner with experience and knowledge, where the Std. Deviation= 1.07 $>1$ ) suggesting this variation in responses. 
Table 4: Participants' Perspective about industry and business knowledge effect on the success of startup in the Kingdom of Bahrain.

\begin{tabular}{|c|c|c|c|c|c|c|c|c|}
\hline \multirow[b]{2}{*}{ Factors } & \multirow[b]{2}{*}{ Statements } & \multicolumn{5}{|c|}{ Frequency \% } & \multirow[b]{2}{*}{ Mean } & \multirow[b]{2}{*}{$\begin{array}{c}\text { Std. } \\
\text { Deviation }\end{array}$} \\
\hline & & $\begin{array}{c}\text { Strongly agree } \\
(5)\end{array}$ & $\begin{array}{c}\text { Agree } \\
\text { (4) }\end{array}$ & $\begin{array}{c}\text { Neutral } \\
\text { (3) }\end{array}$ & $\begin{array}{c}\text { Disagree } \\
\text { (2) }\end{array}$ & $\begin{array}{c}\text { Strongly } \\
\text { disagree } \\
\text { (1) }\end{array}$ & & \\
\hline \multirow{4}{*}{ 4. Knowledge } & $\begin{array}{l}\text { 4.1. I don't have } \\
\text { any prior } \\
\text { knowledge or } \\
\text { information in my } \\
\text { startup field, I just } \\
\text { had an innovative } \\
\text { idea and decided to } \\
\text { establish it. }\end{array}$ & $\begin{array}{c}54 \\
23.4 \%\end{array}$ & $\begin{array}{c}82 \\
35.55\end{array}$ & $\begin{array}{c}33 \\
14.3 \%\end{array}$ & $\begin{array}{c}42 \\
18.2 \%\end{array}$ & $\begin{array}{c}20 \\
8.7 \%\end{array}$ & 3.468 & 1.2675 \\
\hline & $\begin{array}{l}\text { 4.2. I have studied } \\
\text { the field of my } \\
\text { startup and made a } \\
\text { research prior to } \\
\text { the launch of my } \\
\text { startup. }\end{array}$ & $\begin{array}{c}45 \\
19.5 \%\end{array}$ & $\begin{array}{c}102 \\
44.2 \%\end{array}$ & $\begin{array}{c}50 \\
21.6 \%\end{array}$ & $\begin{array}{c}23 \\
10 \%\end{array}$ & $\begin{array}{c}7 \\
3 \%\end{array}$ & 3.683 & 1.0026 \\
\hline & $\begin{array}{l}4.3 . \text { I think prior } \\
\text { knowledge of a } \\
\text { founder in the } \\
\text { startup field does } \\
\text { not affect its } \\
\text { success. }\end{array}$ & $\begin{array}{c}26 \\
11.3 \%\end{array}$ & $\begin{array}{c}52 \\
22.5 \%\end{array}$ & $\begin{array}{c}60 \\
26 \%\end{array}$ & $\begin{array}{c}76 \\
32.9 \%\end{array}$ & $\begin{array}{c}14 \\
6.1 \%\end{array}$ & 3.000 & 1.1264 \\
\hline & $\begin{array}{l}\text { 4.4. I think failure } \\
\text { in a previous } \\
\text { startup will support } \\
\text { an entrepreneur } \\
\text { positively and } \\
\text { affect the success } \\
\text { of his current } \\
\text { startup }\end{array}$ & $\begin{array}{c}55 \\
23.8 \%\end{array}$ & $\begin{array}{c}91 \\
39.4 \%\end{array}$ & $\begin{array}{c}64 \\
27.7 \%\end{array}$ & $\begin{array}{c}17 \\
7.4 \%\end{array}$ & $\begin{array}{c}2 \\
0.9 \%\end{array}$ & 3.786 & .9237 \\
\hline
\end{tabular}




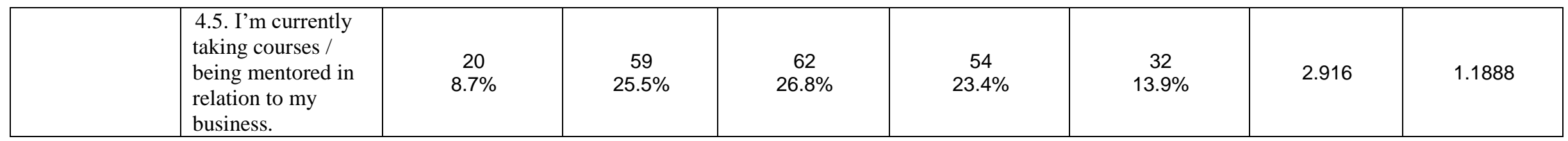

The majority of the founders (mean $\mu=3.683$ and Std. Deviation $=1.0026$ ) emphasized the importance of studying the field of the startup and conducting a research prior to the launch of the startup which will enhance the rates of success. The vast majority of respondents asserted that having a prior knowledge have a great impact on their success, out of the total number of respondents, $32.9 \%$ who agreed with the statement. This indicates that industry or field knowledge is perceived as a significant factor compared to other important aspects including taking courses or having business mentors. It is worth mentioning that $39.4 \%$ of the respondents agreed that previous business failure support the success of the current startup, while 79 of the total respondents are being mentored and taking business courses to increase their business knowledge. 


\section{Hypothesis Testing}

T-test is another test applied to determine the validity of each hypothesis. The hypothesis represents the factors that affect the success of startups in the Kingdom of Bahrain through statements in the survey measuring the participants' opinion about the impact of the four factors on the success of startups in Bahrain.

Based on the findings from t-test analysis a definite conclusion can be extracted regarding research hypothesis. The coefficients are statistically and significantly different to zero if the significance level (p-value) is less than 0.05 , which means rejecting the null hypothesis and accepting the alternative hypotheses, where the hypothesis requires the availability of three conditions in order to accept the alternative hypothesis where the Mean is less than 3 , a t-test value more than 1.96 and a significance level lower than 0.05 . Therefore, due to the criteria to the dependent variables, the significance level (p-value) was less than 0.05 in relation to "Experience" and "Knowledge". These sub hypotheses were accepted, suggesting that there is a statistically significant relationship between each of these factors and success of startups in Bahrain.

On other hand, significance level (p-value) for other factors were more than 0.05 in relation to "Fund raising" and "Partnership" which mean that these sub hypotheses were rejected suggesting that there is no statistically significant relationship between each of these factors and success of startups in Bahrain.

Table 8: Hypothesis Testing

\begin{tabular}{|l|l|l|l|l|l|}
\hline \multicolumn{1}{|c|}{ Hypothesis } & Mean & St.d & t-test & Sig. & Result \\
\hline $\begin{array}{l}\text { H1-1: Raising funds } \\
\text { from an investor or a } \\
\text { financial supporting } \\
\text { entity has significant } \\
\text { positive impact on the } \\
\text { success of startups in } \\
\text { the Kingdom of } \\
\text { Bahrain }\end{array}$ & 2.969 & 0.654 & 0.722 & 0.471 & Reject \\
\hline $\begin{array}{l}\text { H1-2: Having a } \\
\text { business experience has } \\
\text { significant positive } \\
\text { impact on the success } \\
\text { of a startup in the } \\
\text { Kingdom of Bahrain. }\end{array}$ & 3.277 & 0.592 & 7.089 & 0.000 & Accept \\
\hline $\begin{array}{l}\text { H1-3: Partnerships have } \\
\text { a significant positive } \\
\text { impact on the success } \\
\text { of startups in the } \\
\text { Kingdom of Bahrain. }\end{array}$ & 3.023 & 0.880 & 0.404 & 0.687 & Reject \\
\hline
\end{tabular}




\begin{tabular}{|l|l|l|l|l|l|}
\hline $\begin{array}{l}\text { H1-4: Having an } \\
\text { industry and business } \\
\text { knowledge have } \\
\text { significant positive } \\
\text { impact on the success } \\
\text { of startups in the } \\
\text { Kingdom of Bahrain }\end{array}$ & 3.367 & 0.599 & 9.356 & 0.000 & Accept \\
\hline
\end{tabular}

- Sig. is .471 , Mean is 2.969 and t-test is 0.722 which represents a negative correlation between the dependent variable "Success of startups in Bahrain" and independent variables "fund raising".

- Sig. is zero, Mean is 3.277 and t-test is 7.089which represents positive correlation between the dependent variable "Success of startups in Bahrain" and independent variables "experience".

- Sig. is 0.687 , Mean is 3.023and t-test is 0.404 which represents a negative correlation between the dependent variable "Success of startups in Bahrain" and independent variables "partnership".

- Sig. is zero, Mean is 3.367 and t-test is 9.356 which represents positive correlation between the dependent variable "Success of startups in Bahrain" and independent variables "knowledge".

\section{- Research Discussion}

The quantitative research finding shows that "knowledge" was considered as the most significant influencing factor concerning the success of startups in the Kingdom of Bahrain. with the highest t-test (9.356) and Mean (3.367). Interestingly, the research results agree with the literature review. Where most of the researchers emphasized on the knowledge impact on successfully raising funds and on the success of startups in general (Laine, et al. 2019). The results also confirm the indications made by (McCoshan et al., 2010) who concluded that a founder knowledge have a positive effect on the competency of the business and on producing the desired outcome. In the contrast, the results disagree with (Prohorovs, 2018) who stated that knowledge and education in specific product or industry is not presented as a major factor in decision making and not considered as a major element for success. Out of the total respondents of this research, $44 \%$ studied the field of their startups prior to launching their businesses.

The respondents ranked "Experience" as the second most significant factor influencing the success of startups in the Kingdom of Bahrain. with a t-test of (7.089) and Mean (3.277) indicating that the experience has a significant positive impact on the success of startups in the Kingdom of Bahrain. The respondents suggested that the reason behind launching their startup is having an experience in the same field which qualify them and provide them a competitive advantage to proceed with the business and consider experience as an essential element for their startup's success. It is worth noting that the literature review highlighted the particular significance of founder's experience. (Stephan 
\& Drencheva 2017) and (Lévesque and Stephan 2019), for instance, stated that experience have both; positive and negative influence, which can be a powerful tool that assist founders in their startups as they experienced how to raise funds or how to address any social issues. Whilst, negative past experiences can also be a strength factor that affects the learning and coping curve of a founder actions in a startup by amending strategies and overcoming the negative experience, on the other hand, respondents disagree with (Ucbasaran et al., 2013), who stated that experience of failure and fear of social consequences can be a setback to a startup founder, with a total percentage of $55.4 \%$ who disagree and strongly disagree that having an experience of failure causes a social embarrassment.

As for "Partnership" variable, the respondents confirmed a negative relationship between this factor and the success of startups in Bahrain. With a t-test of (0.404) and Mean (3.023) indicating that partnership have a negative relationship on the success of startups in the Kingdom of Bahrain. More specifically, respondents agreed that having a partner would add positive effect on their businesses, however, most of the founders are less likely to have a partner in their current startups, where the responds where neutral with regard to their preferences on having an individual partner or an established company in addition to their preference to continue their businesses solely, resulting to having no significant impact of partnership on the success of startups in Bahrain.

(Cantamessa et a,. 2018), correspondingly emphasized on the importance of partners harmony where the lack of harmony among partners, is an essential factor affecting the success of failure of startups, where (Freytag, 2019) also confirmed that partners goals alignments should be taken into consideration, were they are convinced of the value of the other partner or potential partner and in case there is conflict in goals might drive the startup to failure.

It is worth mentioning that the literature review findings have emphasized on the critical role of partnering with established companies as stated by Freytag (2019), that established companies can give the founder an access to so many advantages such as: the acquisition of the client database and taking advantage of the available technology, however, respondents showed a neutral responses toward partnering with established companies.

The responses related to "Fund raising" variable, has also confirmed a negative relationship between this factor and the success of startups in Bahrain. With a t-test of (0.722) and Mean (2.969) indicating that fund raising have a no direct relationship on the success of startups in the Kingdom of Bahrain. Even though, the majority of respondents launched their startup through financial entities funding, through personal loans or business loans, however, $42.4 \%$ was unable to get funds by investors and governmental supporting entities. Even though, respondents with a total agreement responds stated that the available governmental support for startups affected their business positively and affected their startup success, however, This adverse perception may be justified by their inability to get governmental funding from Tamkeen for instance, where a total of $35 \%$ of respondents where funded through banks or personal loans and $31.2 \%$ remained neutral and did not have a clear response on their ability to get Tamkeen's support. The research 
findings, hence, disagree (Awwad, 2018; Prohorovs, 2019; Awwad and Zidan, 2021) who views fund raising as a critical factor in the success of startups. However, the respondents agree with the researcher that fund raising is required during launch stages and remains critical during the remaining stages of developing the business, even with (Cohen 2019) statement, that Government-led accelerators solves many setbacks that might face an entrepreneur trying to keep the startups successful, however, majority of the founders did not use any governmental accelerator where many recommended to increase the number of accelerators and incubators. In this context, (Rose 2012) were in agreement with the obstacles facing the founders with regard to their ability to get funded by an investor. In general, startups founder's success is not highly depending on investors or governmental support, which confirms that fund raising does not have a significant impact on the success of startups in Bahrain.

\section{Conclusions and Recommendations}

This research focused on assessing the success factors of startups in the Kingdom of Bahrain based on founders' perceptions research approach that encompasses research surveys. The quantitative findings (descriptive of variables) determined the significance of the factors that affects the success of startups in the Kingdom. It highlighted the relationship between fund raising, experience, partnership and knowledge from founders' perspectives. In addition, it indicated that the founders rely greatly on their experience in the business field and to ensure having competent knowledge which support their planning, execution, fund raising and all startup stages.

The hypothesis testing and quantitative analysis confirmed the positive impact of "Experience", and "Knowledge" factors in startups success. However, the hypothesis findings failed to confirm the positive impact of "fund raising", and "partnership" factors. Although, participants considered the importance of these factors in the success of startups in the Kingdom, they do not highly agree that they directly impact their success.

At the end, this research finding might shed light on the gap of founders' ability to raise funds by investors and governmental entities such as Tamkeen, in addition to the limited partnership in the current startups in Bahrain by both; established companies and individuals.

\section{Recommendations}

As mentioned earlier, Bahrain Economic Vision 2030, aspires to shift from an economy that depends on oil wealth to an economy driven diversified sectors including startups aiming at sustainable future. Therefore, the higher the rate of successful startups in the kingdom, the more desired goals achieved accomplishing Bahrain's 2030 vision. The recommendations below can be taken to increase the potential of a wider range of successful startups in the Kingdom of Bahrain:

\section{Founders and Entrepreneurs level:}

- Increase knowledge level prior to the launch of the business, knowledge has proved its significant impact on the success of startups during all stages, starting 
from planning stage to expanding stage. Moreover, knowledge provide founders with competitive advantage when trying to convince an investor to fund the business which can be shown as a personal trait of confidence and convincing skills and evidenced by the reflected knowledge in the business plan.

- On the other hand, with many respondents' recommendations to be innovative and create a new business idea that does not exist in the market and by solving a problem the Bahraini community is facing, knowledge would support creative founder and facilitate their business path providing a comprehensive mixture of knowledge and innovation raising the success probability.

- To enhance knowledge, founders are recommended to seek business coaches and mentors to guide them through the success journey, in addition to a regular attendance of related business trainings and courses serving both skills; operational and personal.

- Launching an innovative idea in a field that a founder previously experienced and familiar with the related processes, practices and requirements along with an available network of service providers and end users would enhance the probability of the startup success. Moreover, an experienced partner or an experienced team is an added value to startups and a great potential that allows the founder to utilize their skills, network and efficiency of work, maintaining a highquality output and preserving the founder's vision.

- Fund raising might be of great impact on startups if received by governmental supporting entities, which would decrease the founder's financial risk, however, founders are recommended to have more exposure to investors and financial supporting entities, their investment fields, their conditions and requirements to provide funds, to be taken into consideration before starting the business. Moreover, fund raising, knowledge and personal traits has showed an indirect positive relationship, where funds are being raised mostly by founders of knowledge and personal traits.

- With regard to partnerships, the majority of startups founders in Bahrain are solo founder, therefore, partnering might have great positive impact in case the availability of the two variables that proved their positive relationship with the success of startups in Bahrain; experience and knowledge. Therefore, it is recommended to have a partner with knowledge and experience rather than partners with capital. Moreover, founders are recommended to be partners with individuals or established companies who are sharing the same vision has proved that it will lead to a positive communication and drive the business to smooth success. 
- Governmental accelerators and incubators are a great tool for startups to utilize in lowering their expenses, therefore accelerators and incubators are recommended to be approached by founders.

\section{Governmental supporting entities level:}

- Encourage startups founders by facilitating the conditions of providing financial support, which will reflect positively on the success rate of startups in Bahrain and its economy.

- Allow the entry of governmental employees into the startup business, where those founders with the appropriate knowledge and experience, can have the ability to build an innovative, successful startup, providing a wide range of job vacancies to Bahraini citizens.

- Increase the number of governmental accelerators and incubators to assist founders in their initial and intermediate stage, in addition to extending the period of support to three or four years to allow having a well established and maintained startup.

- Provide training courses regularly during the calendar year, provided by qualified business coaches and mentors to ensure the knowledge growth of entrepreneurs in the Kingdom.

- With appropriate guidelines, a list of qualified business coaches and mentors are to be promoted on the related authorities' websites.

- A list of investors and supporting entities along with their investment fields, conditions and requirements to fund to be provided to any founder prior to his commercial registration.

- Business for startups is recommended to be added to school's syllabus for students to gain knowledge in an early age discovering their interest in business various fields.

\section{Research Limitations}

Assessing the success factors of startups in Bahrain as a research topic is a trending topic in the Middle East. This research is not a comparative approach research, it is limited to assessing four success factors of startups in the Kingdom of Bahrain. Moreover, Success factors of startups as a whole are many and complicated, this study was limited to four of them only. The research was tested on a small sample due to the number of the current startups in Bahrain, which is considered a minor sample that can be tested more widely if tested out of the Kingdom or within the GCC.

\section{Suggestion for Future Research}

The limitations draw attention to further future studies in examining startups success factors from different aspects. Therefore, case and comparative studies are recommended at regional and international levels to evaluate the factors that affect the success of startups positively which will include a higher segment and sample size. other and different 
success factors can be examined, Moreover, assessing the challenges of success for startups would shed more light on the factors that affect success.

\section{References:}

Aldrich, H. E., \& Yang, T. (2012). What did Stinchcombe really mean? Designing research to test the liability of newness among new ventures. Entrepreneurship Research Journal, 2(3), 1-14. https://doi.org/10.1515/2157-5665.1077

Ali, N.K., Hamdan, A. (2020). The impact of financial illiteracy on entrepreneurship: Evidence from Bahrain. Proceedings of the European Conference on Innovation and Entrepreneurship, ECIE, 2020-September, 895-905.

Al-Roubaie, A., Sarea, A., Al Mubarak, M., Hamdan, A. (2020). Contribution of diaspora to entrepreneurship in the Arab world. Proceedings of the European Conference on Innovation and Entrepreneurship, ECIE, 2020-September, 906-910.

Awwad, B. and Zidan, J. (2021.) The Role of the Clearance Crisis on Public Expenditure and Budget Deficit in Palestine. International Journal of Business Ethics and Governance, $\quad 4(1), \quad 1-40 . \quad$ doi: $\quad 10.51325 /$ ijbeg.v4i1.59. https://doi.org/10.51325/ijbeg.v4i1.59

Awwad, B. S. A. (2018). Market power and performance: An Islamic banking perspective. Corporate Ownership \& Control, 15(3-1), 163-171. https://doi.org/10.22495/cocv15i3c1p2. https://doi.org/10.22495/cocv15i3c1p2

Bachher, J. S., \& Guild, P. D. (1996). Financing early stage technology based companies: investment criteria used by investors. Frontiers of Entrepreneurship Research, 996.

Bender, S. and Fish, A. (2000). The transfer of knowledge and the retention of expertise: the continuing need for global assignments. Journal of Knowledge Management, 4(2), 125-137. https://doi.org/10.1108/13673270010372251. https://doi.org/10.1108/13673270010372251

Bernstein, S., Korteweg, A., \& Laws, K. (2017). Attracting early-stage investors: Evidence from a randomized field experiment. The Journal of Finance, 72(2), 509538. https://doi.org/10.1111/jofi. 12470

Bruno, A. V., \& Tyebjee, T. T. (1985). The entrepreneur's search for capital. Journal of Business Venturing, 1(1), 61-74. https://doi.org/10.1016/0883-9026(85)90007-2

Cantamessa, M., Gatteschi, V., Perboli, G., \& Rosano, M. (2018). Startups' roads to failure. Sustainability, 10(7), 2346. https://doi.org/10.3390/su10072346

Cantele, S., Moggi, S., \& Campedelli, B. (2020). Spreading sustainability innovation through the co-evolution of sustainable business models and partnerships. Sustainability, 12(3), 1190. https://doi.org/10.3390/su12031190

Cockayne, D. (2019). What is a startup firm? A methodological and epistemological investigation into research objects in economic geography. Geoforum, 107, 77-87. https://doi.org/10.1016/j.geoforum.2019.10.009

Cockayne, D. G. (2016). Entrepreneurial affect: Attachment to work practice in San Francisco's digital media sector. Environment and Planning D: Society and Space, 34(3), 456-473. https://doi.org/10.1177/0263775815618399

Cohen, S., Fehder, D. C., Hochberg, Y. V., \& Murray, F. (2019). The design of startup accelerators. Research Policy, 48(7),

https://doi.org/10.1016/j.respol.2019.04.003

Diéguez-Soto, J., López-Delgado, P., \& Mariño-Garrido, T. (2020). The influence of family ownership on acquisition activity: The moderating role of acquisition experience. Journal of Small Business Management, 1-33. https://doi.org/10.1080/00472778.2020.1725813 
Florida, R. L. (2005). Cities and the creative class. Psychology Press. https://doi.org/10.4324/9780203997673

Freear, J., Sohl, J. E., \& Wetzel, W. E. (1995). Angels: personal investors in the venture capital market. Entrepreneurship \& Regional Development, 7(1), 85-94. https://doi.org/10.1080/08985629500000005

Freear, J., Sohl, J. E., \& Wetzel, W. (2002). Angles on angels: Financing technologybased ventures - a historical perspective. Venture Capital, 4(4), 275-287. https://doi.org/10.1080/1369106022000024923

Freytag, Rudolf. (2019). Strategic Negotiations: Three Essentials for Successful Partnerships with Startups. Strategy \& Leadership, 47(1), 19-25. https://doi.org/10.1108/SL-11-2018-0115

Ghura, H., Harraf, A., Li, X., Hamdan, A. (2019). The moderating effect of corruption on the relationship between formal institutions and entrepreneurial activity: Evidence from post-communist countries. Journal of Entrepreneurship in Emerging Economies, 12(1), 58-78. https://doi.org/10.1108/JEEE-03-2019-0032

Gill, R. (2002). Cool, creative and egalitarian? Exploring gender in project-based new media work in Euro. Information, communication \& society, 5(1), 70-89. https://doi.org/10.1080/13691180110117668

Hamdan, A.M., Khamis, R., Al Hawaj, A.A., Barone, E. (2019). The mediation role of public governance in the relationship between entrepreneurship and economic growth. International Journal of Managerial Finance, 16(3), 316-333. https://doi.org/10.1108/IJMF-04-2018-0111

Harraf, A., Ghura, H., Hamdan, A., Li, X. (2020). Formal institutions and the development of entrepreneurial activity - the contingent role of corruption in emerging economies. Journal of Entrepreneurship and Public Policy, 10(1), 15-37. https://doi.org/10.1108/JEPP-06-2020-0033

Hoegl, M., \& Gemuenden, H. G. (2001). Teamwork quality and the success of innovative projects: A theoretical concept and empirical evidence. Organization science, 12(4), 435-449. https://doi.org/10.1287/orsc.12.4.435.10635

Jenkins, A. S., Wiklund, J., \& Brundin, E. (2014). Individual responses to firm failure: Appraisals, grief, and the influence of prior failure experience. Journal of Business Venturing, 29(1), 17-33. https://doi.org/10.1016/j.jbusvent.2012.10.006

Kim, B., Kim, H., \& Jeon, Y. (2018). Critical success factors of a design startup business. Sustainability, 10(9), 2981. https://doi.org/10.3390/su10092981

Laine, K., Tynjälä, P., Eteläpelto, A., \& Hämäläinen, R. (2019). Students' self-reported learning outcomes after a business start-up education program. International Journal of Training Research, 17(2), 98-115. https://doi.org/10.1080/14480220.2019.1638621

Lévesque, Moren, and Ute Stephan. (2020). It's Time We Talk About Time in Entrepreneurship. Entrepreneurship Theory and Practice, 44(2), 163-84. https://doi.org/10.1177/1042258719839711

Mason, C., \& Stark, M. (2004). What do investors look for in a business plan? A comparison of the investment criteria of bankers, venture capitalists and business angels. International small business journal,22(3), 227-248. https://doi.org/10.1177/0266242604042377

Mason, M. K. (2017). Worldwide business start-ups. MKM Research Web site. http://www.moyak.com/papers/businessstartups- entrepreneurs.html

McRobbie, A. (2002). Clubs to companies: Notes on the decline of political culture in speeded up creative worlds. Cultural studies, 16(4), 516-531. https://doi.org/10.1080/09502380210139098 
Naqi, M., Hamdan, A. (2020). Entrepreneurial opportunities and challenges in emerging economic. Proceedings of the European Conference on Innovation and Entrepreneurship, ECIE 2020-September, 926-932

Oliva, Fábio Lotti, and Masaaki Kotabe. (2019). Barriers, Practices, Methods and Knowledge Management Tools in Startups. Journal of Knowledge Management, 23(9), 1838-56. https://doi.org/10.1108/JKM-06-2018-0361

Prohorovs, A., Bistrova, J., \& Ten, D. (2019). Startup Success Factors in the Capital Attraction Stage: Founders' Perspective. Journal of East-West Business, 25(1), 2651. https://doi.org/10.1080/10669868.2018.1503211

Rauch, A., \& Frese, M. (2000). Psychological approaches to entrepreneurial success: A general model and an overview of findings. International review of industrial and organizational psychology, 15, 101-142.

Reyad, S., Badawi, S., Hamdan, A. (2020). Assessing the impact of entrepreneurial skills development on self-employment practices amongst Egyptian and Bahraini accounting students in public and private universities. Journal of Islamic Accounting and Business Research, 11(5), 1101-1120. https://doi.org/10.1108/JIABR-07-2017-0102

Rose, D. (2012). How many start-ups in the US get seed/VC funding per year? http://blog.gust.com/how-many-start-ups-in-the-us-get-seedvc-funding-per-year

Schwarzkopf, C. (2016). Fostering innovation and entrepreneurship: Entrepreneurial ecosystem and entrepreneurial fundamentals in the USA and Germany. Springer. https://doi.org/10.1007/978-3-658-13512-6_7

Skala, A., Skala, \& Barlow. (2019). Digital Startups in transition economies. Springer International Publishing. https://doi.org/10.1007/978-3-030-01500-8

Skala, Agnieszka. (2019). Characteristics of Startups. Digital Startups in Transition Economies, Springer International Publishing, 41-91. https://doi.org/10.1007/9783-030-01500-8_2

Stephan U. and Drencheva, A. (2017). The Person in Social Entrepreneurship: A Systematic Review of Research on the Social Entrepreneurial Personality. DOI: https://doi.org/10.1002/9781118970812.ch10

Stucki, T. (2014). Success of start-up firms: the role of financial constraints. Industrial and Corporate Change, 23(1), 25-64. https://doi.org/10.1093/icc/dtt008

Tagliapietra, S. (2019). The impact of the global energy transition on MENA oil and gas $\begin{array}{llll}\text { producers. Energy Strategy } & \text { Reviews, 26, } & 100397 .\end{array}$ https://doi.org/10.1016/j.esr.2019.100397

Tagliapietra, S. (2019). The impact of the global energy transition on MENA oil and gas $\begin{array}{lll}\text { producers. Energy Strategy } & \text { Reviews, 26, } & 100397 .\end{array}$ https://doi.org/10.1016/j.esr.2019.100397

Tengeh, R. K., \& Nkem, L. (2017). Sustaining immigrant entrepreneurship in South Africa: The role of informal financial associations. Sustainability, 9(8), 1396. https://doi.org/10.3390/su9081396

Ucbasaran, D., Shepherd, D. A., Lockett, A., \& Lyon, S. J. (2013). Life after business failure: The process and consequences of business failure for entrepreneurs. Journal of management, 39(1), 163-202. https://doi.org/10.1177/0149206312457823

Wang, M., \& Gibb, J. (2020). Uncovering opportunity: expert vs. novice entrepreneurs use of intuitive and analytical decision-making. In Handbook of Intuition Research as Practice. Edward Plgar https://doi.org/10.4337/9781788979757.00012 